\title{
Virulence and adhesive properties of serotypes $A$ and $B$ of Candida albicans isolated from paediatric burn patients
}

\author{
M. J. KENNEDY, AYODELE M. JOHNSON*‡, P. A. VOLZ*, ALICE N. NEELY† and \\ R. J. YANCEY
}

Therapeutics Research, The Upjohn Company, 7923-190-MR, Kalamazoo, MI 49001, *Mycology Laboratory, Eastern Michigan University, Ypsilanti, MI 48197 and tShriners Burn Institute, Cincinnati, OH 45219, USA

\begin{abstract}
Summary. The virulence and adhesive properties of 50 isolates of Candida albicans serotypes $A$ and $B$ collected over 6 years from 48 paediatric burn patients were examined to provide more detailed information about candidal pathogenesis in burn patients and to examine the relevance of the commonly used epithelial cell adhesion assay for determining fungal virulence. The isolates represented a fair distribution of serotypes ( 29 isolates were serotype A and 21 isolates were serotype B) and a total of 28 serotype-biotype combinations were found; $32 \%$ of the serotype-biotype combinations appeared only once, while $44 \%$ of the isolates showed similar biotype tests for two of three digits. Adhesion of the isolates to plastic and to buccal epithelial cells (BECs) was examined and compared after growth in a chemically defined medium. There were significant differences in the adhesion of individual isolates to plastic or BECs, but no correlation was found between biotype and adhesiveness. Serotype B isolates were found to be more adhesive to BECs $(p<0.05)$ but not to plastic. There was no apparent correlation between candidal adhesiveness and site of isolation from these patients (autografts, blood, faeces, throat swabs, tracheal aspirates, wounds and intravenous catheters), although isolates from catheters were generally less adhesive to epithelial cells. Virulence in a systemic infection mouse model revealed that there were significant differences in virulence between isolates, but no correlation was found between virulence and the biotype, serotype or site of isolation. Similarly, no correlation was found between virulence and adhesiveness or cell-surface hydrophobicity. These results suggest that, although variations in adhesiveness between isolates of $C$. albicans can be detected in an epithelial cell adhesion assay, such tests may not be useful as reliable predictors of virulence. These data also suggest that candidal pathogenesis is the result of a multifactorial process whereby, in some instances, adhesion may play only a transient role in infection.
\end{abstract}

\section{Introduction}

Infections caused by Candida albicans are important causes of morbidity and mortality in burn patients and other immunocompromised individuals. ${ }^{1}$ Much has been speculated about the pathogenesis of this organism, and many virulence factors have been proposed as requisites of candidal pathogenicity. The ability of C. albicans to adhere to various host tissues and implanted prosthetic devices, for example, is considered to be an important event in colonisation and pathogenesis ${ }^{2}$ and this view is supported by the finding that non-adhesive mutants are less virulent or are inferior in colonisation to their wild-type parental strains. ${ }^{3}$ In one of the most widely employed techniques for assessing candidal adhesion, exfoliated epithelial cells are used as the test surface. ${ }^{2}$ However,

Received 24 Aug. 1990; revised version accepted 19 Aug. 1991.

$\ddagger$ Present address: Nigerian Institute for Oceanography and Marine Research, Lagos, Nigeria. while the adhesion of $C$. albicans to epithelial cells has been commonly studied ${ }^{2}$ and appears to be a useful test system to assess the virulence of strains and species of candida, ${ }^{4-6}$ no studies have investigated a large number of well characterised isolates to determine the relevance of such tests. ${ }^{2}$ In the studies that have attempted to investigate the virulence of C. albicans by determining the ability of isolates to attach to epithelial cells in vitro, only 4-6 isolates were examined (half of which have generally been "laboratory strains") and little or no information has been given with regard to site of isolation, serotype, biotype or virulence in an animal model. ${ }^{7}$ Not surprisingly, these reports are inconsistent in their findings regarding the relationship between adhesiveness of C. albicans to exfoliated epithelial cells and virulence. ${ }^{2,8}$ Studies by King et al. $^{4}$, Macura et al. ${ }^{5}$ and McCourtie and Douglas, ${ }^{6}$ for instance, showed that there were significant differences in the ability of pathogenic and non-pathogenic Candida strains and 
species to adhere to exfoliated epithelial cells in vitro. In contrast, Kearns et al. ${ }^{7}$ found that differences in adhesiveness between isolates of $C$. albicans obtained from cases of oral thrush and from the mouths of healthy donors were not only small but were inconsistent in relation to their virulence. Therefore, a large gap remains when such adhesion assays are used to define the role of adhesion and certain cell surface properties (e.g., cell surface hydrophobicity) in the overall colonising or pathogenic ability of C. albicans. ${ }^{2,8}$ The purposes of the present study were to examine the adhesiveness and virulence of a large number of clinical isolates of $C$. albicans, to determine if there was a correlation between these properties and serotype or biotype, and to provide more detailed information about $C$. albicans epidemiology and pathogenesis in paediatric burn patients. Also, the relationship of cell-surface hydrophobicity to C.albicans adhesion and virulence was examined.

\section{Materials and methods}

\section{Candida strains ${ }^{\circ}$}

Fifty isolates of $C$. albicans from various body sites of 48 paediatric burn patients at the Shriners Burn Institute, Cincinnati Unit (Cincinnati, OH, USA) were chosen randomly for study. They were isolated between Jan. 1983 and Dec. 1988 from autografts, blood, faeces, throat swabs, tracheal aspirates, wounds and intravenous catheters. Identification as $C$. albicans was based on the production of germ-tubes after incubation for $2 \mathrm{~h}$ in bovine serum and on growth of the yeasts on a pH 1.55 agar. ${ }^{9}$ Isolates were stored at $-70^{\circ} \mathrm{C}$ in skimmed milk-brain heart infusion broth. C. albicans strains AK785 and CA30 from the oral cavity of a 1 week-old infant with thrush and the blood of a patient with systemic candidosis, respectively, were used as "standards" for these studies, and served as controls to compare experiments performed on different days.

\section{Growth conditions}

For adhesion assays, isolates of C. albicans were grown on Sabouraud Maltose Agar (Difco) at $22-24^{\circ} \mathrm{C}$ for 1-4 days. A loopful of cells was then transferred to $100 \mathrm{ml}$ of the medium of Lee et al. (designated here LBC $)^{10}$ supplemented with $50 \mathrm{~mm}$ glucose and the culture was incubated aerobically at $25^{\circ} \mathrm{C}$ with shaking at $100 \mathrm{rpm} .{ }^{11}$ For LD50 determinations, yeast cells were grown for 16-18 h on Sabouraud Dextrose Agar (SDA; Difco) at $37^{\circ} \mathrm{C}$. Preliminary studies showed that there was no significant difference in virulence of isolates of C. albicans grown on SDA or LBC, or at different temperatures. For biotyping, yeasts were streaked on to SDA slants for revival, and then grown on yeast nitrogen base-glucose agar immediately before biotyping.

\section{Cell preparation}

After growth, the yeast cells were collected by centrifugation and the pellet was washed twice in either $0.01 \mathrm{M}$ phosphate-buffered saline (PBS) ${ }^{11}$ at pH 7.2 or buffered $\mathrm{KCl}(\mathrm{B}-\mathrm{KCl})^{12,13}$ for adhesion tests with buccal epithelial cells (BECs) or plastic, respectively. The Candida cells were suspended to give a final concentration of $2 \times 10^{7} / \mathrm{ml}$ for adhesion to BECs or $5 \times 10^{6} / \mathrm{ml}$ for adhesion to plastic. These concentrations were selected because they allowed for maximal adhesion with little or no complication due to co-adhesion. ${ }^{11-14}$

\section{Mucosal cells}

BECs were collected from a healthy female adult by gently rubbing the inside of her cheeks with sterile cotton swabs and suspending the cells in PBS. The donor had no signs or symptoms of oral thrush and had not taken antibiotics for at least 12 months. Cells were washed three times in PBS, resuspended to a concentration of $2 \times 10^{5}$ cells $/ \mathrm{ml}$ in PBS, as determined by haemocytometer count, and stored at $4^{\circ} \mathrm{C}$ until required (maximum 2 weeks). Previous studies showed that storage of BECs did not affect the adhesion of C. albicans, ${ }^{11}$ but controls were included throughout the 2-week experimental period to ensure that differences in adhesion were not due to the use of either fresh or stored BECs. Examination by light microscopy confirmed that none of the cell samples contained mucosal cells already colonised by yeasts.

\section{Adhesion assays}

Adhesion of C.albicans to BECs was assayed as described previously. ${ }^{11}$ Briefly, 0.2-ml samples of BECs and yeast cells were placed into small test tubes $(12 \times 75 \mathrm{~mm})$ and incubated on a rotary shaker $(180 \mathrm{rpm})$ for $1 \mathrm{~h}$ at $37^{\circ} \mathrm{C}$. After incubation, BECs were collected and washed on polycarbonate filters (12- $\mu \mathrm{m}$ pore size) (Nucleopore Corporation, Pleasanton, CA, USA). Cells were washed with approximately $100 \mathrm{ml}$ of $\mathrm{B}-\mathrm{KCl}$ with continual (gentle) agitation. The filters were then stained with Gram's crystal violet, and the number of $C$. albicans adhering to 100 BECs was determined by light microscopy ( $\times 430$ magnification). Experiments were repeated three times.

The adhesion of C.albicans cells to plastic was studied with polystyrene microtitration trays (Costar, Cambridge, MA, USA) containing 48 11-mm-diameter wells, as described previously. ${ }^{12,13}$ Briefly, a 0.5 $\mathrm{ml}$ sample of a suspension of C. albicans cells was placed in each well, the tray was incubated for $1 \mathrm{~h}$ at $25^{\circ} \mathrm{C}$ without shaking, and the wells were then washed three times with $1 \mathrm{ml}$ of assay medium. After incubation of the assay mixture and washing, the trays were inverted and allowed to dry overnight at room temperature. Adherent $C$. albicans were counted by light microscopy, without staining, at $\times 100 ; 5-10$ 
1- $\mathrm{mm}^{2}$ fields were counted per well, and the assay was performed 4-6 times for each isolate. Only the central area of each well was included in the counting procedure because several non-adherent $C$. albicans cells were deposited at the outer edge of the wells during the drying process. Occasionally, clear patches with few or no yeast cells were observed around or near the centre of the well, and were not included in the areas to be counted. This method provided an efficient and reproducible assay for quantitating the adhesion of $C$. albicans to plastic. ${ }^{12,13}$

\section{Phase-partition test for cell surface hydrophobicity}

A phase-partition test employing hexadecane as the hydrocarbon phase was used to determine $C$. albicans cell-surface hydrophobicity as described previously. ${ }^{14}$ Briefly, $2.5 \mathrm{ml}$ of washed C. albicans cells $\left(1 \times 10^{8}\right.$ cells/ $\mathrm{ml}$ ) was mixed vigorously with $0.5 \mathrm{ml}$ of hexadecane and the two liquids were allowed to partition. After separation, the optical density of the aqueous phase was measured at $400 \mathrm{~nm}$ with a Spectronic 20 spectrophotometer (Bausch and Lomb, Inc., Rochester, NY, USA). The relative cell-surface hydrophobicity was then determined by measuring the difference in absorbencies of test and control cells, and determining the percentage of cells that had entered the alkane phase.

\section{Serotype testing}

C. albicans serotypes were distinguished on the basis of reactions of agglutination (serotype A) or nonagglutination (serotype B) with Candida-check antiserum 6 (Iatron, Inc., Tokyo, Japan), as described previously. ${ }^{1}$

\section{Biotype testing}

The modified method of Odds and Abbott, ${ }^{15}$ with commercially available methods of preparing and plating inocula, ${ }^{16}$ was used to determine the biotype of each isolate. Briefly, by assessing the growth of each isolate on nine agar plates of various chemical composition, this system determined an isolate's
pH 1.4 and salt tolerance; 5 -fluorocytosine, borate and safranin resistance; production of proteinase; and assimilation of urea, sorbose and citrate. Agar plates were inoculated and incubated at $37^{\circ} \mathrm{C}$. The nine biochemical tests were grouped in sets containing three tests each. A positive result for each test was assigned a specific numerical value and no growth on a test plate was scored as 0 . The summation of these from each set determined a 3-digit biotype for each isolate (table I).

\section{LD50 determinations}

The lethality of each isolate was determined in a systemic infection mouse model with 21-day-old female CD-1 mice (Charles Rivers) weighing c. $14 \mathrm{~g}$. After growth on one SDA plate for $16-18 \mathrm{~h}$ at $37^{\circ} \mathrm{C}$, a lawn of each isolate was suspended in $8 \mathrm{ml}$ of sterile Brain Heart Infusion Broth (BHI; Difco) supplemented with brewers yeast (BHI-BY) $4 \% \mathrm{v} / \mathrm{v}$ final concentration. Serial 10 -fold dilutions were made in BHI-BY, and $0.5 \mathrm{ml}$ of C.albicans suspension was injected intraperitoneally into each mouse. Each dilution group contained 10 mice and mortality was monitored daily for 2 weeks. The relative virulence of each isolate was compared to the virulence of an experimental control (CA30) to allow direct comparison between isolates tested on different days.

\section{Statistical analyses}

To test if there was a statistical difference between serotype $\mathrm{A}$ and serotype $\mathrm{B}$ of $C$. albicans for distribution in patients, virulence, or a particular adhesive property tested, the one-way analysis of variance test procedure was used. All contrasts were done with $\alpha=0.05$.

\section{Results}

\section{Biotype and serotype distribution}

The distribution of serotypes and biotypes among C. albicans isolates from various body sites is shown in

Table I. Arrangement of biotyping tests results to give biotype number

\begin{tabular}{|c|c|c|c|c|c|}
\hline \multicolumn{2}{|c|}{ Digit 1} & \multicolumn{2}{|c|}{ Digit 2} & \multicolumn{2}{|c|}{ Digit 3} \\
\hline Test & $\begin{array}{l}\text { Score for } \\
(+) \text { result }\end{array}$ & Test & $\begin{array}{l}\text { Score for } \\
(+) \text { result }\end{array}$ & Test & $\begin{array}{l}\text { Score for } \\
(+) \text { result }\end{array}$ \\
\hline $\begin{array}{l}\mathrm{pH} 1.4 \\
\text { tolerance }\end{array}$ & 1 & $\begin{array}{l}\text { Urea } \\
\text { assimilation }\end{array}$ & 1 & $\begin{array}{l}\text { Citrate } \\
\text { assimilation }\end{array}$ & 1 \\
\hline $\begin{array}{l}\text { Proteinase } \\
\text { production }\end{array}$ & 2 & $\begin{array}{l}\text { Sorbose } \\
\text { assimilation }\end{array}$ & 2 & $\begin{array}{l}\text { Borate } \\
\text { resistance }\end{array}$ & 2 \\
\hline $\begin{array}{l}\text { 5-Fluorocytosine } \\
\text { resistance }\end{array}$ & 4 & $\begin{array}{l}\text { Salt } \\
\text { tolerance }\end{array}$ & 4 & $\begin{array}{l}\text { Safranin } \\
\text { resistance }\end{array}$ & 4 \\
\hline
\end{tabular}

The positive results for each test are scored as indicated. All negative results are scored as 0 . The sum of the results for the three tests in that column gives the biotype digit. 
Table II. Biotypes of C. albicans serotypes A and B isolated from paediatric burn patients

\begin{tabular}{|c|c|c|c|c|}
\hline \multirow{2}{*}{$\begin{array}{l}\text { Site of } \\
\text { isolation }\end{array}$} & \multicolumn{2}{|c|}{ Serotype A } & \multicolumn{2}{|c|}{ Serotype B } \\
\hline & $\begin{array}{c}\text { Isolate } \\
\text { identification }\end{array}$ & Biotype & $\begin{array}{c}\text { Isolate } \\
\text { identification }\end{array}$ & Biotype \\
\hline Autograft & $\begin{array}{l}862391 \\
862500 \\
880005 \\
881480\end{array}$ & $\begin{array}{l}054 \\
152 \\
350 \\
152\end{array}$ & $\begin{array}{l}852424 \\
872762 \\
881110-3 \\
881322\end{array}$ & $\begin{array}{l}274 \\
056 \\
170 \\
456\end{array}$ \\
\hline Blood & $\begin{array}{l}840892 \\
851446 \\
870853\end{array}$ & $\begin{array}{l}076 \\
157 \\
072\end{array}$ & 833325 & 456 \\
\hline Faeces & $\begin{array}{l}840276 \\
851886 \\
860755 \\
862703\end{array}$ & $\begin{array}{l}056 \\
156 \\
152 \\
052\end{array}$ & $\begin{array}{l}833048 \\
843975 \\
860710 \\
880672\end{array}$ & $\begin{array}{l}456 \\
376 \\
476 \\
057\end{array}$ \\
\hline Throat swab & $\begin{array}{l}851928 \\
862042-3 \\
870893-2 \\
871862-3 \\
872339-3\end{array}$ & $\begin{array}{l}056 \\
072 \\
276 \\
042 \\
474\end{array}$ & $\begin{array}{l}832847 \\
853616 \\
880412-2\end{array}$ & $\begin{array}{l}056 \\
456 \\
656\end{array}$ \\
\hline $\begin{array}{l}\text { Tracheal } \\
\text { aspirate }\end{array}$ & $\begin{array}{l}840248 \\
842114 \\
871124-5 \\
871764\end{array}$ & $\begin{array}{l}056 \\
156 \\
152 \\
152\end{array}$ & $\begin{array}{l}862400-4 \\
870028-3 \\
880764-3 \\
880882-3\end{array}$ & $\begin{array}{l}476 \\
170 \\
556 \\
472\end{array}$ \\
\hline Wound & $\begin{array}{l}840881 \\
850383 \\
862071-5 \\
880435-2\end{array}$ & $\begin{array}{l}076 \\
257 \\
270 \\
350\end{array}$ & $\begin{array}{l}833005 \\
853586 \\
870097 \\
872620\end{array}$ & $\begin{array}{l}456 \\
456 \\
456 \\
477\end{array}$ \\
\hline $\begin{array}{l}\text { Intravenous } \\
\text { catheter }\end{array}$ & $\begin{array}{l}832890 \\
840811 \\
850189 \\
851440 \\
872904-4\end{array}$ & $\begin{array}{l}052 \\
256 \\
357 \\
157 \\
072\end{array}$ & 860642 & 576 \\
\hline
\end{tabular}

table II. The strains represented a fair distribution of serotypes ( 29 isolates were serotype $A$ and 21 isolates were serotype B) isolated from 48 patients over a 6year period. Within the 50 isolates examined, a total of 28 serotype-biotype number combinations were found; $32 \%$ of the serotype-biotype combinations appeared only once. A total of $44 \%$ of all isolates showed similar biotype test results for two of three digits: partial biotypes for the first and second threeset tests were $18 \%$, first and third $14 \%$, and second and third $12 \%$. Of the serotype $\mathrm{A}$ isolates, $31 \%$ had the partial biotype $15-; 33 \%$ of all serotype $B$ isolates had the partial biotype 45-. No general trend was observed for $C$. albicans biotype or serotype and site of isolation. The single exception was for wound isolates for serotype B, of which three of four isolates had a biotype of 456 .

\section{Adhesion of $C$. albicans serotypes and biotypes}

To determine whether serotype, biotype or site of isolation had any influence on $C$. albicans adhesion and virulence, all 50 isolates were compared in a battery of experimental models. Since not all strains could be run at the same time for each experiment, two strains of C. albicans (AK785 and CA30) that had been well characterised in these systems were used as experimental controls and as a means of comparing experiments performed on different days. As is summarised in tables III and IV, there was no apparent correlation between the site of isolation and adhesion to plastic or BECs. There were significant differences in adhesiveness between individual isolates and, generally, serotype B was more adhesive than serotype A to plastic. Serotype B (mean adhesion value $30.6 \mathrm{SEM} 2 \cdot 7 \mathrm{C}$. albicans/BEC) was significantly more adhesive to BECs $(p<0.05)$ than serotype A (mean adhesion value 22.4 SEM 1.7 C. albicans/BEC), although no one biotype predominated. No analysis could be made of biotypes that appeared singly, but amongst those biotypes that appeared more than once there was no correlation between adhesion to plastic or BECs. The only exception to this was the finding that $83 \%$ of biotype 456 isolates showed attachment to BECs that was lower than the median adhesion level, and $88 \%$ of isolates with the partial biotype 15 -showed attachment to plastic that was lower than the median adhesion level.

\section{Cell-surface hydrophobicity of C. albicans serotypes and biotypes}

A comparison was made between the cell-surface hydrophobicity of the isolates and their serotype, biotype and site of isolation. As is summarised in 
Table III. Adhesion of C. albicans serotypes A and B to plastic

\begin{tabular}{|c|c|c|c|c|}
\hline \multirow{2}{*}{$\begin{array}{l}\text { Site of } \\
\text { isolation }\end{array}$} & \multicolumn{2}{|c|}{ Serotype A } & \multicolumn{2}{|c|}{ Serotype B } \\
\hline & $\begin{array}{c}\text { Isolate } \\
\text { identification }\end{array}$ & $\begin{array}{l}\text { Mean number of } \\
\text { yeast } / \mathrm{mm}^{2}\end{array}$ & $\begin{array}{c}\text { Isolate } \\
\text { identification }\end{array}$ & $\begin{array}{l}\text { Mean number of } \\
\text { yeast } / \mathrm{mm}^{2}\end{array}$ \\
\hline Autograft & $\begin{array}{l}862391 \\
862500 \\
880005 \\
881480\end{array}$ & $\begin{array}{r}10.9 \\
41.9 \\
2.4 \\
137.2\end{array}$ & $\begin{array}{l}852424 \\
872762 \\
881110-3 \\
881322\end{array}$ & $\begin{array}{r}92.9 \\
112.6 \\
11.7 \\
81.0\end{array}$ \\
\hline Blood & $\begin{array}{l}840892 \\
851446 \\
870853\end{array}$ & $\begin{array}{r}3.5 \\
37.6 \\
151.3\end{array}$ & 833325 & $125 \cdot 6$ \\
\hline Faeces & $\begin{array}{l}840276 \\
851886 \\
860755 \\
862703\end{array}$ & $\begin{array}{r}62 \cdot 5 \\
4 \cdot 8 \\
42 \cdot 2 \\
5 \cdot 2\end{array}$ & $\begin{array}{l}833048 \\
843975 \\
860710 \\
880672\end{array}$ & $\begin{array}{l}73 \cdot 3 \\
12 \cdot 8 \\
10 \cdot 8 \\
22 \cdot 6\end{array}$ \\
\hline Throat Swab & $\begin{array}{l}851928 \\
862042-3 \\
870893-2 \\
871862-3 \\
872339-3\end{array}$ & $\begin{array}{r}29 \cdot 3 \\
25 \cdot 3 \\
181.6 \\
13.8 \\
24.5\end{array}$ & $\begin{array}{l}832847 \\
853616 \\
880412-2\end{array}$ & $\begin{array}{r}15 \cdot 8 \\
17 \cdot 3 \\
159 \cdot 5\end{array}$ \\
\hline $\begin{array}{l}\text { Tracheal } \\
\text { aspirate }\end{array}$ & $\begin{array}{l}840248 \\
842114 \\
871124-5 \\
871764\end{array}$ & $\begin{array}{r}9 \cdot 6 \\
9 \cdot 0 \\
16 \cdot 3 \\
1 \cdot 0\end{array}$ & $\begin{array}{l}862400-4 \\
870028-3 \\
880764-3 \\
880882-3\end{array}$ & $\begin{array}{r}15 \cdot 4 \\
272 \cdot 2 \\
7 \cdot 0 \\
182 \cdot 4\end{array}$ \\
\hline Wound & $\begin{array}{l}840881 \\
850383 \\
862071-5 \\
880435-2\end{array}$ & $\begin{array}{r}35 \cdot 9 \\
8 \cdot 3 \\
80 \cdot 9 \\
68 \cdot 0\end{array}$ & $\begin{array}{l}833005 \\
853586 \\
870097 \\
872620\end{array}$ & $\begin{array}{r}140 \cdot 3 \\
159 \cdot 4 \\
131 \cdot 4 \\
40 \cdot 0\end{array}$ \\
\hline $\begin{array}{l}\text { Intravenous } \\
\text { catheter }\end{array}$ & $\begin{array}{l}832890 \\
840811 \\
850189 \\
851440 \\
872904-4\end{array}$ & $\begin{array}{r}69 \cdot 0 \\
98 \cdot 8 \\
5 \cdot 4 \\
48 \cdot 1 \\
3 \cdot 7\end{array}$ & 860642 & $91 \cdot 5$ \\
\hline
\end{tabular}

table $\mathrm{V}$, there was no significant difference between the cell-surface hydrophobicities of these two serotypes. Furthermore, with the exception of biotype 456 ( $71 \%$ of which had greater cell-surface hydrophobicity than the median level) there was no biotype that showed either an increase or decrease in cell-surface hydrophobicity; however, in general, safranin resistant isolates were more hydrophobic than safranin intolerant ones. A comparison of cell-surface hydrophobicities with adhesion to plastic and BECs revealed that there was no correlation between these properties. Similarly, there was no correlation between cellsurface hydrophobicity and virulence.

\section{Virulence of C. albicans serotypes and biotypes}

To determine whether serotype, biotype, site of isolation or adhesiveness had an influence on virulence in a systemic infection mouse model, a comparison was made of the relative virulence of each isolate and these other properties. Table VI summarises the virulence of $C$. albicans serotypes and biotypes in the model. As can be seen from the table, there were significant differences in the virulence of individual strains, but these differences could not be linked to any particular biotype, partial biotype or serotype.
Similarly, there was no significant difference between the virulence of $C$. albicans isolates from various body sites. A comparison of the adhesive properties of individual strains, regardless of serotype, biotype or site of isolation, indicated that there was no apparent correlation between adhesion and virulence in the mouse model used in the present study. Differences in adhesion and virulence were found not to be due to storage of the isolates.

\section{Discussion}

There is a large gap in the current knowledge of the pathogenesis of candidal infections. There has been much speculation over the past decade regarding C. albicans virulence factors and many determinants of virulence have been proposed. ${ }^{9}$ Similarly, numerous reports have mentioned differences in virulence between serotypes and strains of $C$. albicans or the preponderance of specific strains in certain patient populations. 9 This has led to the study of isolated factors thought to be of importance in candidal infections as well as to the development of several typing schemes that may serve as predictors of fungal virulence. ${ }^{9}$ In the present study, several factors that 


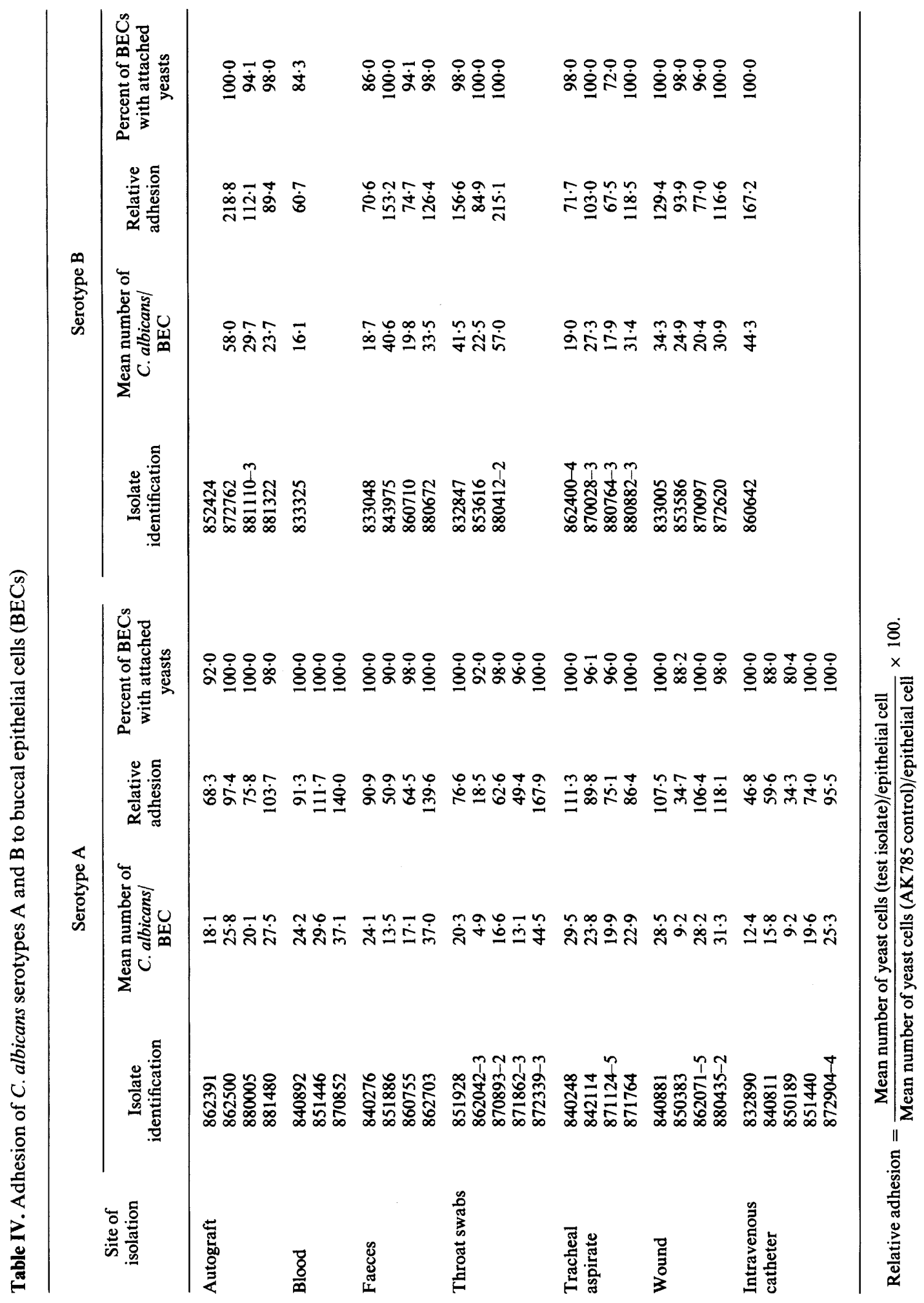


Table V. Cell-surface hydrophobicity (CSH) of C. albicans serotype A and B

\begin{tabular}{|c|c|c|c|c|}
\hline \multirow{2}{*}{$\begin{array}{l}\text { Site of } \\
\text { isolation }\end{array}$} & \multicolumn{2}{|c|}{ Serotype A } & \multicolumn{2}{|c|}{ Serotype B } \\
\hline & $\begin{array}{c}\text { Isloate } \\
\text { identification }\end{array}$ & $\begin{array}{l}\text { Percent of cells } \\
\text { entering the } \\
\text { alkane phase }\end{array}$ & $\begin{array}{c}\text { Isolate } \\
\text { identification }\end{array}$ & $\begin{array}{c}\text { Percent of cells } \\
\text { entering the } \\
\text { alkane phase }\end{array}$ \\
\hline Autograft & $\begin{array}{l}862391 \\
862500 \\
880005 \\
881480\end{array}$ & $\begin{array}{r}6 \cdot 2 \\
13 \cdot 6 \\
9 \cdot 1 \\
15 \cdot 0\end{array}$ & $\begin{array}{l}852424 \\
872762 \\
881110-3 \\
881322\end{array}$ & $\begin{array}{c}0 \\
0 \\
0 \\
13.6\end{array}$ \\
\hline Blood & $\begin{array}{l}840892 \\
851446 \\
870853\end{array}$ & $\begin{array}{r}18 \cdot 2 \\
9 \cdot 1 \\
8 \cdot 3\end{array}$ & 833325 & $23 \cdot 6$ \\
\hline Faeces & $\begin{array}{l}840276 \\
851886 \\
860755 \\
862703\end{array}$ & $\begin{array}{c}22 \cdot 7 \\
0 \\
11.9 \\
0.9\end{array}$ & $\begin{array}{l}833048 \\
843975 \\
860710 \\
880672\end{array}$ & $\begin{array}{r}4 \cdot 5 \\
10 \cdot 8 \\
19 \cdot 2 \\
20 \cdot 8\end{array}$ \\
\hline Throat swabs & $\begin{array}{l}851928 \\
862042-3 \\
870893-2 \\
871862-3 \\
872339-3\end{array}$ & $\begin{array}{c}25 \cdot 0 \\
0 \\
8 \cdot 3 \\
5 \cdot 0 \\
13 \cdot 7\end{array}$ & $\begin{array}{l}832847 \\
853616 \\
880412-2\end{array}$ & $\begin{array}{r}8 \cdot 3 \\
13 \cdot 0 \\
22 \cdot 8\end{array}$ \\
\hline $\begin{array}{l}\text { Tracheal } \\
\text { aspirate }\end{array}$ & $\begin{array}{l}840248 \\
842114 \\
871124-5 \\
871764\end{array}$ & $\begin{array}{c}16 \cdot 7 \\
0 \\
11 \cdot 4 \\
0\end{array}$ & $\begin{array}{l}862400-4 \\
870028-3 \\
880764-3 \\
880882-3\end{array}$ & $\begin{array}{r}27 \cdot 3 \\
0 \cdot 8 \\
6 \cdot 5 \\
17 \cdot 5\end{array}$ \\
\hline Wound & $\begin{array}{l}840881 \\
850383 \\
862071-5 \\
880435-2\end{array}$ & $\begin{array}{r}20 \cdot 4 \\
16 \cdot 8 \\
27 \cdot 3 \\
9 \cdot 1\end{array}$ & $\begin{array}{l}833005 \\
853586 \\
870097 \\
872620\end{array}$ & $\begin{array}{r}18 \cdot 2 \\
18 \cdot 1 \\
2 \cdot 4 \\
6 \cdot 8\end{array}$ \\
\hline $\begin{array}{l}\text { Intravenous } \\
\text { catheter }\end{array}$ & $\begin{array}{l}832890 \\
840811 \\
850189 \\
851440 \\
872904-4\end{array}$ & $\begin{array}{c}0 \\
15 \cdot 5 \\
6 \cdot 8 \\
33 \cdot 3 \\
18.7\end{array}$ & 860642 & $9 \cdot 5$ \\
\hline
\end{tabular}

might influence virulence were examined in isolates from one pathogenic setting-paediatric burn patients.

The most widely studied virulence factor for C. albicans is attachment to epithelial cells. ${ }^{17}$ Although recent studies by Calderone and co-workers have shown through the use of non-adhesive mutants that adhesion to host tissues plays an important role in C. albicans virulence, ${ }^{3}$ it has not been determined whether a transient or permanent adhesion is required for pathogenesis. Thus, while adhesion may be required to initiate infection, these initial adhesive interactions may later give way to some other means of tissue localisation (e.g., entrapment in liver sinusoids or fibrin-platelet clots), in which case some other virulence mechanism would be likely to be of more importance. ${ }^{2}$ The impression given by some reports that adhesion is the most important virulence factor in candidal infections, or that simple tests such as adhesion to exfoliated epithelial calls can be used to assess fungal virulence, remain to be proved.

The results of the present study reaffirm that adhesion alone does not account for C.albicans virulence and that this property cannot be relied upon as a predictor of virulence for this organism. The present data also confirm the findings of Hasenclever and Mitchell ${ }^{18}$ that differences in virulence could not be distinguished on the basis of serotype. Furthermore, these data are in agreement with the suggestion that current biotyping schemes for $C$.albicans cannot identify strains with high or low virulence attributes. ${ }^{9}$ It was also of particular interest to note that there was no apparent difference in adhesive or virulence abilities of the strains related to site of isolation.

Perhaps the most striking findings in this study was the increased ability of $C$. albicans serotype B to adhere to BECs. This was particularly striking because there was no significant difference in cell-surface hydrophobicity, adhesion to plastic or virulence in mice. Analysis of mannans isolated from serotypes A and B of $C$. albicans has revealed differences between the mannans of these serotypes. These differences appear to be due to extent of branching, the length of the side chain (serotype $A$ is thought to have longer side chains), and the proportion and position of $\alpha-1,2-$ linkages in the side chains. ${ }^{2}$ Whether these differences may account for the difference in adhesion to BECs is not known. ${ }^{2}$

The finding that there was no correlation between cell-surface hydrophobicity and adhesion to either BECs or plastic is consistent with recent findings. ${ }^{1-14}$ For instance, white and opaque phenotypes of 


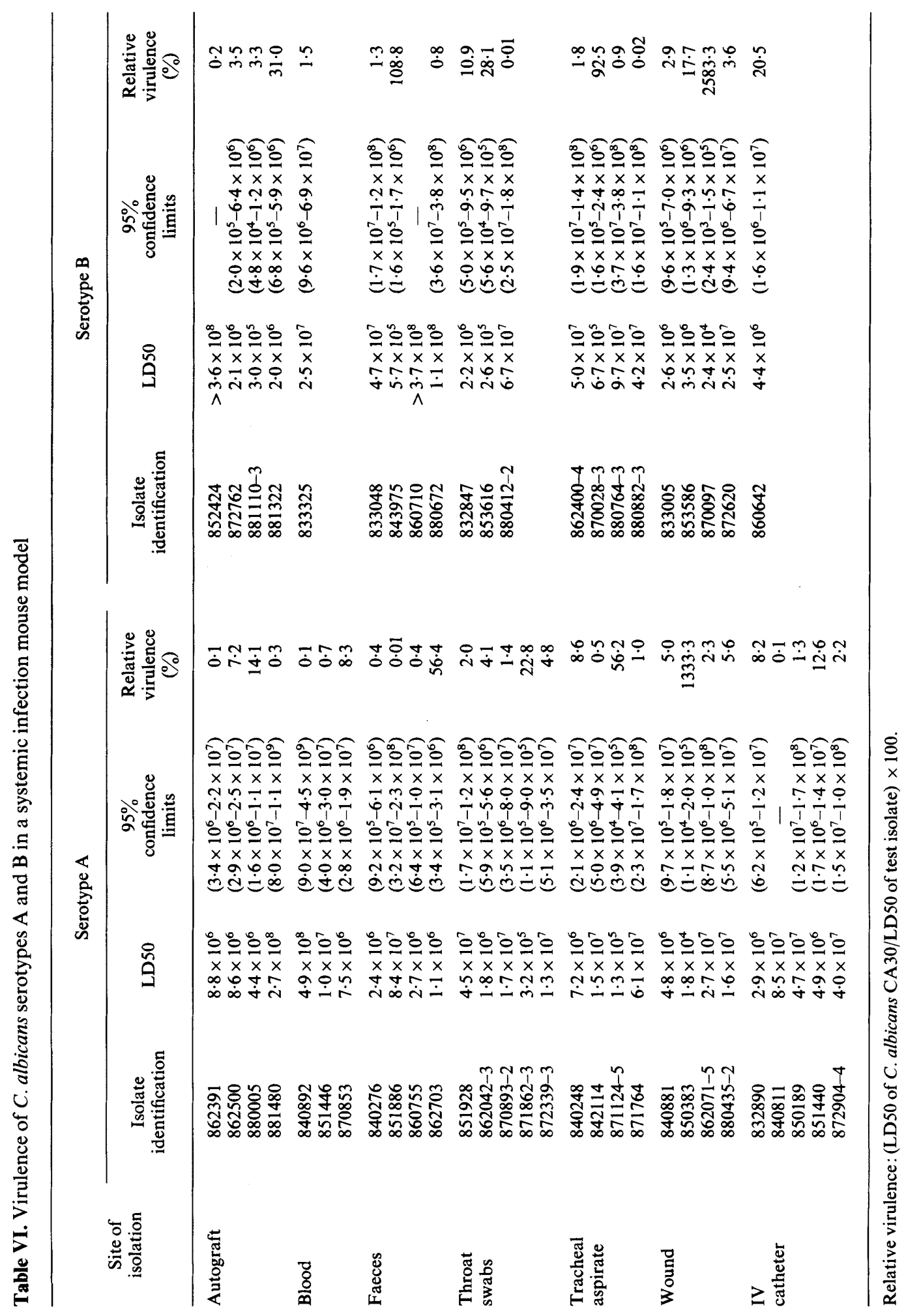


C. albicans were found to differ significantly in their cell-surface hydrophobicity but this difference did not account for the difference in adhesive properties between these two isolates. ${ }^{12,13}$ Similarly, other studies that have examined the possible role of cell surface hydrophobicity in adhesion to BECs and intestinal mucosa, suggest that this property plays only

\section{References}

1. Neely AN, Odds FC, Basatia BK, Holder IA. Characterisation of Candida isolates from pediatric burn patients. $J$ Clin Microbiol 1988; 26: 1645-1649.

2. Kennedy MJ. Adhesion and association mechanisms of Candida albicans. Curr Top Med Mycol 1988; 2: 73-169.

3. Calderone RA, Cihlar RL, Lee DD-S, Hoberg K, Scheld WM Yeast adhesion in the pathogenesis of endocarditis due to Candida albicans: studies with adherence-negative mutants. $J$ Infect Dis $1985 ; 152: 710-715$.

4. King RD, Lee JC, Morris AL. Adherence of Candida albicans and other Candida species to mucosal epithelial cells. Infect Immun 1980; $27: 667-674$.

5. Macura AB, Pawlik B, Wita B. Candida adherence to mucosal epithelial cells with regard to its pathogenicity. Zentralbl Bakteriol Mikrobiol Hyg I Abt Orig A 1983; 254: 561-565.

6. McCourtie J, Douglas LJ. Relationship between cell surface composition, adherence, and virulence of Candida albicans. Infect Immun 1984; $45: 6-12$.

7. Kearns MJ, Davies $P$, Smith $H$. Variability of the adherence of Candida albicans strains to human buccal epithelial cells : inconsistency of differences between strains related to virulence. Sabouraudia 1983; 21 : 93-98.

8. Kennedy MJ. Models for studying the role of fungal attachment in colonization and pathogenesis. Mycopathologia 1990; 109: 123-127

9. Odds FC. Candida and candidosis, 2nd edn. Philadelphia, Bailliére Tindall. 1988.

10. Lee KL, Buckley HR, Campbell CC. An amino acid liquid synthetic medium for the development of mycelial and a minor role in these processes. ${ }^{19}$ The present study, together with the latter studies, seem to cast doubt on the suggestion that cell-surface hydrophobicity is the principle mechanism of adhesion to plastic and suggests that this property should be studied in greater detail to determine its precise role in the adhesion of C. albicans to biological and non-biological surfaces.

yeast forms of Candida albicans. Sabouraudia 1975; 13: 148-153.

11. Kennedy MJ, Sandin RL. Influence of growth conditions on Candida albicans adhesion, hydrophobicity and cell wall ultrastructure. J Med Vet Mycol 1988; 26: 79-92.

12. Kennedy MJ, Rogers AL, Hanselmen LR, Soll DR, Yancey RJ. Variation in adhesion and cell surface hydrophobicity in Candida albicans white and opaque phenotypes. $\mathrm{Myco}$ pathologia $1988 ; 102$ : 149-156.

13. Kennedy MJ, Rogers AL, Yancey RJ. Environmental alteration and phenotypic regulation of Candida albicans adhesion to plastic. Infect Immun 1989; 57: 3876-3881.

14. Kennedy MJ, Volz PA, Edwards CA, Yancey RJ. Mechanisms of association of Candida albicans with intestinal mucosa. J Med Microbiol 1987; 24: 333-341.

15. Odds FC, Abbott AB. A simple system for presumptive identification of Candida albicans and differentiation of strains within the species. Sabouraudia 1980; 18: 301-317.

16. Childress CM, Holder IA, Neely AN. Modifications of a Candida albicans biotyping system. J Clin Microbiol 1989; 27: $1392-1394$.

17. Hunter PR, Fraser CAM, MacKenzie DWR. Morphotype markers of virulence in human candidal infections. $J$ Med Microbiol 1989; 28: 85-91.

18. Hasenclever HF, Mitchell WO. Antigenic studies of Candida. III. Comparative pathogenicity of Candida albicans group A, group B and Candida stellatoidea. J Bacteriol $1961 ; 82$ : 578-581.

19. Klotz SA, Penn RL. Multiple mechanisms may contribute to the adherence of Candida yeasts to living cells. Curr Microbiol 1987; 16: 119-122. 